\title{
Direct evidence of cannibalism in the Oligocene cutlassfish Anenchelum glarisianum Blainville, 1818 (Perciformes: Trichiuridae)
}

\author{
TOMÁŠ PŘIKRYL \& BRONISLAV NOVOSAD
}

\begin{abstract}
Cannibalism in ancient fishes is an interesting paleobiological fact which has rarely been identified in the fossil record. One such case is described here. The specimen of a partly preserved Trichiuridae fish, Anenchelum glarisianum, contains the remains of prey inside the body cavity. Two types of prey can be identified, one of which is A. glarisianum. The heads of the prey are oriented posteriorly inside the body cavity. On the basis of analogy with recent populations of trichiurid fish from Taiwan, cannibalism most likely resulted from a paleoecologic imbalance in the population of A. glarisianum in Litenčice. Other known data on the feeding habits of fossil Trichiuridae are mentioned. - Key words: Trichiuridae, cannibalism, feeding habits, fish, paleobiology, cutlassfish.
\end{abstract}

PŘIKRYL, T. \& NovosAD, B. 2009. Direct evidence of cannibalism in the Oligocene cutlassfish Anenchelum glarisianum Blainville, 1818 (Perciformes: Trichiuridae). Bulletin of Geosciences 84(3), 569-572 (2 figures, 2 tables). Czech Geological Survey, Prague. ISSN 1214-1119. Manuscript received November 26, 2008; accepted in revised form March 2, 2009; published online July 28, 2009; issued September 11, 2009.

Tomáš Přikryl, Institute of Geology, Academy of Sciences of the Czech Republic, v.v.i., Rozvojová 269, CZ-165 00 Praha 6, Czech Republic, and Institute of Geology and Paleontology, Charles University in Prague, Albertov 6, CZ-128 43 Praha 2, Czech Republic; prikryl@gli.cas.cz•Bronislav Novosad, Kunín 27, 74253 Kunin;B.Novosad@seznam.cz.

Cannibalism is defined as the act of a species eating its own. Such behavior in recent fishes has been studied by many authors (e.g., summarizing article by Smith \& Reay 1991) and filial cannibalistic behavior has been studied by Manica (2002). Cannibalistic dietary habits were recognized not only in recent fish populations, but in fossil fish assemblages also (see Table 1). Viohl (1990) focused mainly on ichthyoliths from the Solnhofen Limestone which contains information about piscivory, including cannibalism in fishes at different stratigraphic levels. There are two recognized positions for prey inside the predator's cavity as evidenced by fossils: head oriented posteriorly (prey swallowed head first) and head oriented anteriorly (prey swallowed tail first, e.g. Boucot 1990).

Members of the Trichiuridae are benthopelagic predators feeding on fishes, squid and crustaceans (Parin 1986, Nakamura \& Parin 1991). Cannibalism in this group was de-
Table 1. Direct evidence of cannibalistic behavior in fossil fishes, from Viohl (1990) with data presented here. Abbreviations: A. - Anenchelum, I. - Incisoscutus, S. - Serranus, U. - Urocles.

\begin{tabular}{llll}
\hline taxon & $\begin{array}{l}\text { head orientation } \\
\text { (Boucot 1990) }\end{array}$ & stratigraphy & references \\
\hline A. glarisianum & posteriorly & Oligocene & $\begin{array}{l}\text { Přikryl \& } \\
\text { Novosad }\end{array}$ \\
Cearana sp. & posteriorly & $\begin{array}{l}\text { Lower } \\
\text { Cretaceous }\end{array}$ & Case 1982 \\
& & Upper Devonian & Denis \& Miles \\
I. ritchei & posteriorly & Frasnian & 1981 \\
S. budensis & posteriorly & Oligocene & Pauca 1931 \\
Spaniodon sp. & anteriorly & Upper & Woodward \\
& & Cretaceous & 1901 \\
Undina sp. & posteriorly & Jurassic & Watson 1927, \\
& & & Schultze 1972 \\
U. polyspondylus & $?$ & Jurassic & Viohl 1990 \\
\hline
\end{tabular}

scribed by Luo (1991) from the waters of the East China Sea and by Lee (1978) from waters of Taiwan. Direct evidence of cannibalism in fossil trichiurids has not been published until now. The only known feeding habit data on fossil Trichiuridae (without cannibalistic evidence) were published by Jaroš (1937), who described a Lepidopus glarisianus (SL = $525 \mathrm{~mm}$ ) specimen from Vážany nad Litavou locality (Czech Republic) which contained a Merluccius latus prey individual (SL about $120 \mathrm{~mm}$ ), and by von Rath (1859) who described an Anenchelum glarisianum specimen, from Glarn canton in Switzerland (Plattenberges locality), which contained fish remains in the body cavity.

The material described here was collected from an outcrop at Litenčice village (17 km north-west from Kroměřiž). This locality has provided a rich assemblage of fish and additional fauna (e.g., Gregorová 1988, Gregorová \& Mlynarski 1993). Gregorová (1988) provided description of the locality and its biostratigraphic position which indicates similarity to zone NP 23 in the Dynow Marlstones (on the basis of calcareous nannofossils).

\section{Material and methods}

The studied specimens, numbered 1 and 2 (part and counterpart), are deposited in Bronislav Novosad's collection in 
the Kunín chateau. The fish is on a slab of menilitic shale, part of the body, lacking the head and distal part of the tail, along with the contents of the body cavity are preserved (Fig. 1A, B). The fossil specimens were left unprepared. All measurements are in millimeters.

Anatomical abbreviations: AX - axonosts; BD - body depth; NCR - neurocranium; P - pectoral fin; SL - standard length; VERT - vertebrae.

Institutional abbreviations: IGP - Institute of Geology and Paleontology, Charles University, Prague.

\section{Systematic section}

Family Trichiuridae Rafinesque, 1810

Subfamily Aphanopodinae Gill, 1863

\section{Genus Anenchelum Blainville, 1818}

\section{Anenchelum glarisianum Blainville, 1818}

Descriptions. - A) Predator: The Anenchelum glarisianum specimen has an estimated SL of about $240 \mathrm{~mm}$. The partially preserved vertebral column contains 61 vertebrae. Behind the ventral part of the shoulder girdle, a pectoral fin is present. The body depth at the pectoral fin level is $15 \mathrm{~mm}$. Neither the dorsal nor the anal fin are preserved, but many of their axonosts are clearly visible. The body cavity, starting at the level of the pectoral girdle, is about $80 \mathrm{~mm}$ long. Inside the body cavity of this specimen the remains of its prey are preserved.

B ) Prey: On first sight it is possible to recognize parts of vertebral columns and skull elements. Two types of prey vertebrae belonging to two taxa can be recognized (Figs $1 \mathrm{C}, 2$ ). The summary of measurements and vertebrae counts are presented in Table 2.

B A) Prey 1: The first type of prey has a vertebra in articulation with the relict of its skull. The vertebrae are relatively long, with short, straight neural and hemal spines. On a few vertebrae positioned closely behind the skull, it is possible to see the neural spines in articulation with the axo-

Table 2. The detailed measurements and vertebrae counts for specimens 1 and 2. Abbreviation: A. - Anenchelum.

\begin{tabular}{lccc}
\hline & predator & \multicolumn{2}{c}{ prey } \\
\hline & A. glarisianum & A. glarisianum & Scopeloides sp. \\
\hline estimated SL & $240 \mathrm{~mm}$ & $140 \mathrm{~mm}$ & - \\
maximal BD & $17 \mathrm{~mm}$ & - & - \\
NCR length & - & $19 \mathrm{~mm}$ & - \\
NCR width & - & $7 \mathrm{~mm}$ & - \\
preserved VERT & 61 & 30 & 16 \\
\hline
\end{tabular}

nosts of the dorsal fin (Fig. 1C). About 30 vertebrae are preserved and are interrupted to represent the middle of the vertebral column. The relict of the skull, probably the neurocranium, is preserved in dorsal view. The length of the preserved part of the skull is $19 \mathrm{~mm}$ and its width is $7 \mathrm{~mm}$. The separate bones are not recognizable. In front of the skull a triradiate element is present which may be part of the same skull. The position of the prey inside the body cavity is with the tail orientated anteriorly. The head is twisted so that it also has an anterior orientation (Fig. 2).

B B ) Prey 2: The other preserved prey specimen is morphologically different. The vertebrae centra are slightly tapered in the middle (distinctly more so than in the first prey type), the neural and hemal spines are relatively long and distal parts of the spines are turned slightly posteriorly. There are 16 vertebrae in the preserved part of the spine and no other skeletal elements are preserved. The head is orientated posteriorly inside the body cavity.

\section{Discussion}

On the basis of a detailed description of prey remains, it is possible to distinguish two taxa:

The first type of prey is likely to be the remains of a young A. glarisianum individual, based mainly on the morphology of vertebrae and neural spines which are articulated with typical dorsal fin axonosts (Fig. 1C). The estimated SL of the prey specimen Anenchelum is about $150 \mathrm{~mm}$. The vertebral column is twisted behind the head, so that the specimen has both its tail and the top of its head orientated anteriorly. This position could indicate: a) that the prey was caught just behind the head and swallowed from the middle of the body so that the fish was folded during swallowing; or b) the head is situated in the proximal part of gut, which subsequently twisted so that the head is orientated anteriorly. Turning of prey in the stomach is highly improbable. On the basis of the position of the specimen and comparison with recent representatives of Trichiuridae, it is possible to exclude viviparity.

The second prey specimen is different. The tapered centra in the middle of the spine and the long neural and hemal spines with its distal parts turned posteriorly, links this specimen with the genus Scopeloides, which are common in the same layers at the locality. These fishes are close relatives to the recent genus Gonostoma (Stomiiformes, Gonostomatidae) (e.g., Kalabis 1938-40, Arambourg 1967, Daniltshenko 1960). The same vertebrae morphotype was recognize in the A. glarisianum body cavity from the Plattenberges locality (Glarn canton) in Switzerland (Přikryl, personal observation), which is housed in the collection of the IGP - specimen number 4636.

On the specimen from Litenčice, the prey position in the predator body is with the head orientated posteriorly, 


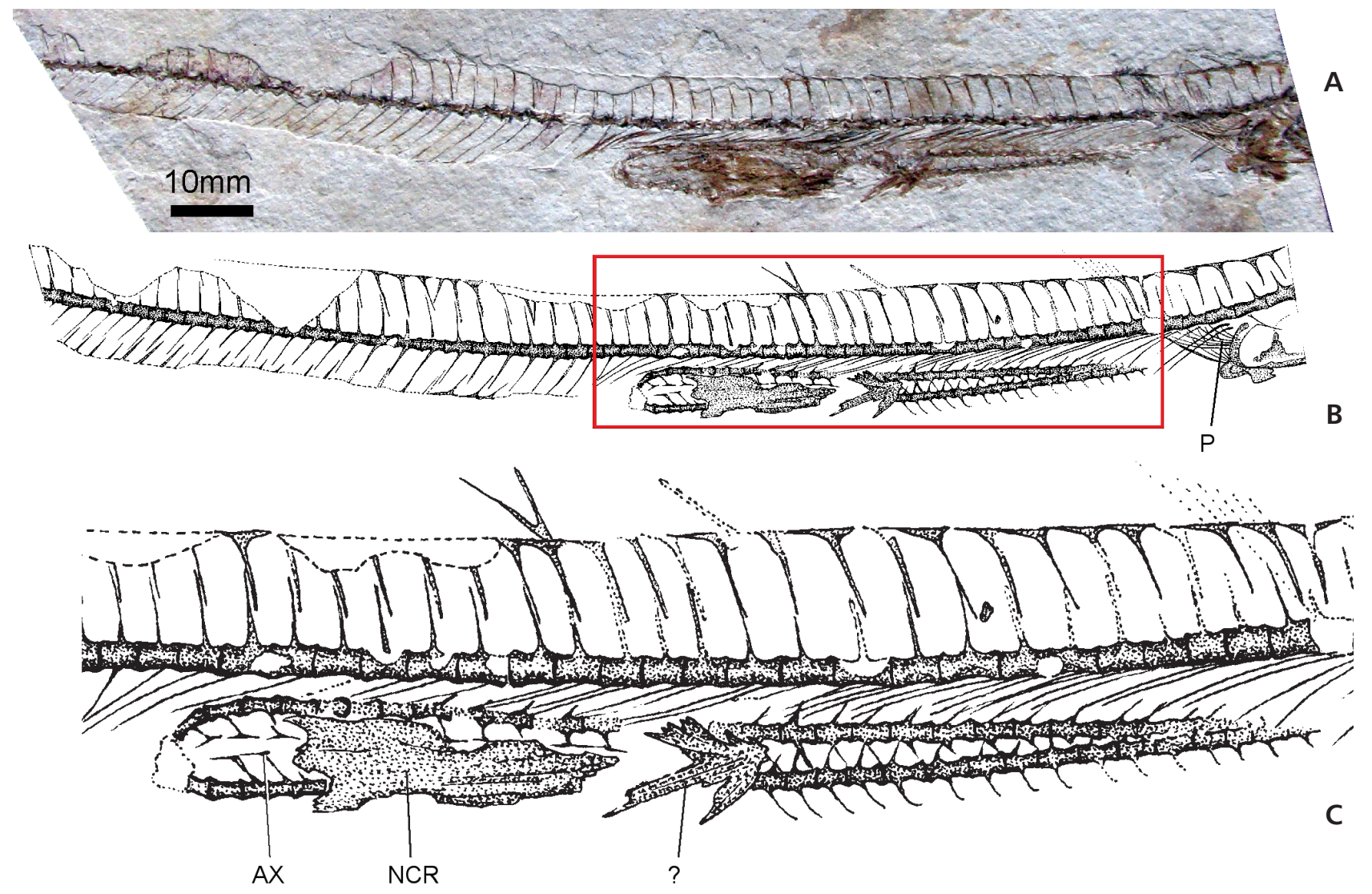

Figure 1. Anenchelum glarisianum. Litenčice locality. $\bullet \mathrm{A}$ - photo of specimen number $1 . \bullet \mathrm{B}$-drawing of specimen number 1 . $\bullet \mathrm{C}-\operatorname{detail}$ of red box in $\mathrm{B}$.

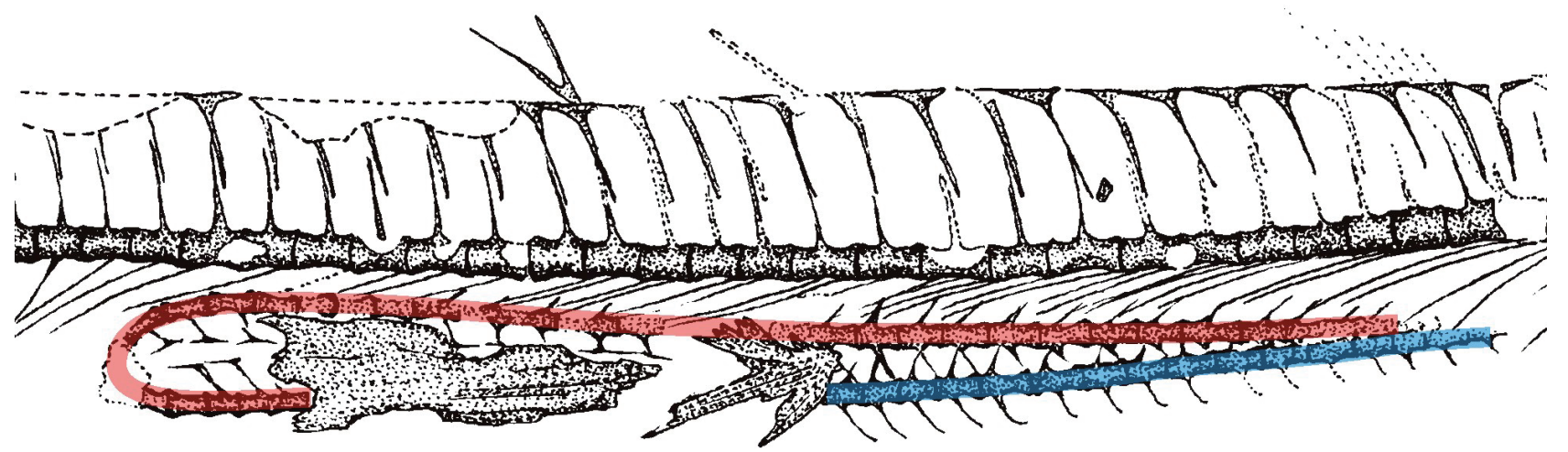

Figure 2. Anenchelum glarisianum. Detail of the body cavity distinguishing the two prey specimens.

i.e. swallowed head first (in the Anenchelum prey specimen it is difficult to determine what was the cause of the twisted head) and it is the most common orientation of prey in fossil predator fish specimens (Viohl 1990). However, head first consumption of prey in Anenchelum in not likely due to the position of the gonostomatid prey inside the body cavity of specimen IGP 4636 (from the Plattenberges locality) in which the head is orientated anteriorly. This prey position is quite unusual in the Paleogene and has been mentioned only in connection with some specimens from the Monte Bolca locality (Viohl 1990).
The feeding habits of recent Trichiuridae fish are generally relatively well known and it is possible to compare it with present knowledge of fossil Anenchelum specimens. Parin (1986) and Nakamura \& Parin (1991) described a diet consisting mainly of a variety of fishes, squid and crustaceans. Cannibalism was described by Luo (1991) and Lee (1978) from western Pacific waters. Chiou et al. (2006) stated that the rare occurrence of cannibalism among the ribbonfish Trichiurus lepturus may be attributed to their low population density and inadequate supply of food. Therefore, it is expected that there were some other factors acting in the 
paleoenvironment in which the sediments at the Litenčice locality were deposited. Fossils of A. glarisianus are common in many localities in Moravia and comprise $15 \%$ of the fish fauna in Dynow Marlstones at the Litenčice locality (according to Gregorová 1997). This could suggest a paleoecologically imbalanced population and/or insufficient food sources, as in the model cases from Pacific waters (Luo 1991, Lee 1978), potentially resulting in occasional cannibalistic behavior. Evaluation of this interpretation awaits the recovery of additional Anenchelum specimens with preserved prey.

\section{Results}

On the basis of direct fossil evidence, cannibalism in the Oligocene species Anenchelum glarisianum is recognized. Skeletal remains found in the body cavities of the specimens studied here and other studied specimens, show predator-prey relationships with fishes from the family Gonostomatidae. The position of prey inside the body cavity in this studied specimen is with the head orientated posteriorly. However, this position is not consistent in this taxon, as can be seen in the specimen from the IGP collection.

On the basis of analogy with recent Trichiuridae fishes from the waters of Taiwan, it can be suggested that there was a paleoecological imbalance in the A. glarisianum population at the Litenčice locality such that a reduced food supply resulted in cannibalism.

\section{Acknowledgements}

We are grateful to J.G. Eaton who kindly made linguistic improvements, and A.M. Murray and an anonymous reviewer for constructive suggestions which greatly improved the quality of the manuscript. This work was supported by institutional project AVOZ30130516 of the Geological Institute of the Czech Academy of Sciences, v.v.i.

\section{References}

ARAmbourG, C. 1967. Les Poissons oligocénes de l'Iran. Notes et Mémoires sur le Moyen-Orient 8, 9-210.

BLAINVILLE, H.M. DE 1818. Sur les ichthyolites ou les poissons fossiles, 310-395. Nouveau Dictionnaire d'Histoire Naturelle, applique aux Arts, à l'Agriculture, à l'Economie Rurale et Domestique, à la Medicine 27. Deterville, Paris.

BouCOT, A.J. 1990. Evolutionary paleobiology of behavior and coevolution. 725 pp. Elsevier, London.

CASE, G.R. 1982. A pictorial guide to fossils. 309 pp. Van Nostrand Reinhold Co., New York.

ChIOU, W.-D., ChEn, C.-Y., WANG, C.-M. \& CHEN, C.-T. 2006. Food and feeding habits of ribbonfish Trichiurus lepturus in coastal waters of south-western Taiwan. Fisheries Science 72(2), 373-381. DO] 10.1111/j.1444-2906.2006.01159.x
DANILTSHENKO, P.G. 1960. Kostistiye ryby maikopskich othlozeniy Kavkaza. Trudy Paleontologicheskogo Instituta AN SSSR 78, 1-208.

DENIS, K. \& MILES, R.S. 1981. Pachyosteomorph arthrodire from Gogo, Western Australia. Zoological Journal of Linnean Society 73(3), 213-258. DOI 10.1111/j.1096-3642.1981.tb01594.x

GILL, T. 1863. Synopsis of the family of lepturoids, and description of a remarkable new generic type. Proceedings of the Academy of the Natural Sciences of Philadelphia 1863, 224-229.

GREGOROVÁ, R. 1988. Rybí fauna menilitového souvrství na lokalitě Litenčice a její stratigrafická pozice. Acta Musei moraviae, Scientiae naturales 73, 83-88.

GREGOROVÁ, R. 1997. Vývoj společenstev rybí a žraločí fauny v oligocénu vnějších Západních Karpat (Morava) a jejich význam pro paleoekologii, paleobatymetrii a stratigrafii, 29-35. In HLADILOVÁ, Š. (ed.) Dynamika vztahů marinního a kontinentálního prostředí. Masarykova univerzita v Brně, Brno.

GrEgOROVÁ, R. \& MLYNARSKI, M. 1993. Premiere découverte de Glarichelys knorri (Gray), tortue marine (Cheloniidae) dans l'Oligocene des couches a ménilite de Moravie (Tchécoslovaquie). Acta Musei moraviae, Scientiae naturales 77, 63-69.

JAROŠ, Z. 1937. Paleogenní rybí fauna z Linhartských Vážan od Slavkova u Brna. Časopis Vlasteneckého spolku musejního v Olomouci 50, 99-106.

KALABIS, V. 1938-40. Ryby se světelnými orgány z menilitových břidlic moravských a způsob života jejich recentních forem ve Středozemním moři. Věstník Klubu prrírodovědeckého v Prostějově 26, 1-6.

LEE, S.C. 1978. Food and feeding habits of ribbonfishes, Trichiurus japonicus and T. lepturus. Bulletin of the Institute of Zoology, Academia Sinica 17, 117-124.

LUO, B. 1991. Cutlassfish, 111-113. In FAN, C.Q. (ed.) Marine Fishery Biology. Agriculture Press, Beijing.

MANICA, A. 2002. Filial cannibalism in teleost fish. Biological Reviews 77(2), 261-277. DOI 10.1017/S1464793101005905

NAKAMURA, I. \& PARIN, N.V. 1991. FAO species catalogue. Vol. 15. Snake mackerels and cutlassfishes of the world (Families Gempylidae and Trichiuridae). 136 pp. FAO of the United Nations, Rome.

PARIN, N.V. 1986. Trichiuridae, 976-980. In WHITEHEAD, P.J.P., BAuChOt, M.-L., HuREAU, J.-C., NiELSEN, J. \& TORTONESE, E. (eds) Fishes of the north-eastern Atlantic and the Mediterranean. Vol. 2. UNESCO, Paris.

PAUCÃ, M. 1931. Die fossile fauna und flora aus dem Oligozan von Suslanesti-Muscel in Rumänia. Anuarul Instiutului Geologic al Romaniei 16, 575-668.

RAFINESQUE, C.S. 1810. Indice d'ittiologia siciliana; ossia, catalogo metodico dei nomi latini, italiani, e siciliani dei pesci, che si rinvengono in Sicilia disposti secondo un metodo naturale e seguito da un appendice che contiene la descrizione de alcuni nuovi pesci sicilian. 70 pp. Giovanní del Nobolo, Messina.

VON RATH, G. 1859. Beiträge zur Kenntniss der fossilen Fische des Plattenberges im Canton Glarus. Zeitschrift der Deutschen Geologischen Gesellschaft 11, 108-132.

SCHULTZE, H.-P. 1972. Early growth stages in coelacanth fishes. Nature: New Biology 236(64), 90-91.

SMith, C. \& REAY, P. 1991. Cannibalism in teleost fish. Reviews in Fish Biology and Fisheries 1(1), 41-64.

DOI 10.1007/BF00042661

VIOHL, G. 1990. Piscivorous fishes of the Solnhofen lithographic limestone, 287-303. In BOUCOT, A.J. Evolutionary paleobiology of behavior and coevolution. Elsevier, London.

WATSON, X. 1927. The reproduction of the coelacanth fish Undina. Proceedings of the Zoological Society of London 28, 453-457. 